\title{
Hoe Creek 1990 Quarterly Sampling Cumulative Report
}

\author{
Topical Report
}

S.E. Crader

G.S. Huntington

March 1991

Work Performed Under Cooperative Agreement No.: DE-FC21-86MC11076

For

U.S. Department of Energy

Office of Fossil Energy

Morgantown Energy Technology Center

Morgantown, West Virginia

By

Western Research Institute

Laramie, Wyoming

\section{MFSTER}




\section{DISCLAIMER}

This report was prepared as an account of work sponsored by an agency of the United States Government. Neither the United States Government nor any agency thereof, nor any of their employees makes any warranty, express or implied, or assumes any legal liability or responsibility for the accuracy, completeness or usefulness of any information, apparatus, product, or process disclosed, or represents that its use would not infringe privately owned rights. Reference herein to any specific commercial product, process, or service by trade name, trademark, manufacturer, or otherwise, does not necessarily constitute or imply its endorsement, recommendation, or favoring by the United States Government or any agency thereof. The views and opinions of authors expressed herein do not necessarily state or reflect those of the United States Government or any agency thereof.

This report has been reproduced directly from the best available copy.

Available to DOE and DOE contractors from the Office of Scientific and Technical Information, P.O. Box 62, Oak Ridge, TN 37831; prices available from (615)576-8401, FTS 626-8401.

Available to the public from the National Technical Information Service, U.S. Department of Commerce, 5285 Port Royal Rd., Springfield, VA 22161. 
DOE/MC/11076-3062

(DE92001143)

\title{
Hoe Creek 1990 Quarterly Sampling Cumulative Report
}

\author{
Topical Report
}

S.E. Crader

G.S. Huntington

Work Performed Under Cooperative Agreement No.: DE-FC21-86MC11076

\author{
For \\ U.S. Department of Energy \\ Office of Fossil Energy \\ Morgantown Energy Technology Center \\ P.O. Box 880 \\ Morgantown, West Virginia 26507-0880 \\ By \\ Western Research Institute \\ P.O. Box 3395 \\ University Station \\ Laramie, Wyoming $8207 \mathrm{i}$
}

March 1991 
IIST OF FIGURES $\ldots \ldots \ldots \ldots \ldots \ldots \ldots \ldots \ldots \ldots \ldots \ldots \ldots \ldots \ldots \ldots$

SUMMARY $\ldots \ldots \ldots \ldots \ldots \ldots \ldots \ldots \ldots \ldots \ldots \ldots \ldots \ldots \ldots \ldots \ldots \ldots \ldots \ldots$

INTRODUCTION.................................. 1

RESULTS AND DISCUSSION ............................ 2

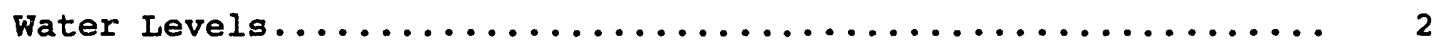

Contamination concentrations...................... 4

Channel sands: Benzene........................... 5

Channel sands: Total phenols....................... 5

Hoe Creek I/II, Felix 2: Benzene..................... 5

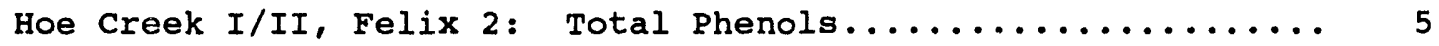

Hoe Creek I/II, Felix 1: Benzene..................... 8

Hoe Creek I/II, Felix 1: Total Phenols................. 8

Hoe Creek III, Felix 2: Benzene and Total phenols.......... 8

Hoe Creek III, Felix 1: Benzene and Total Phenols.......... 8

Temporal Changes in Contamination Concentrations........... 8

ConCLusIONS .....................................

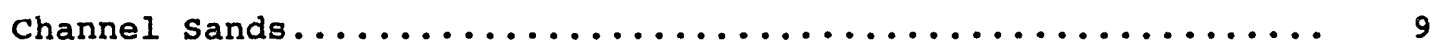

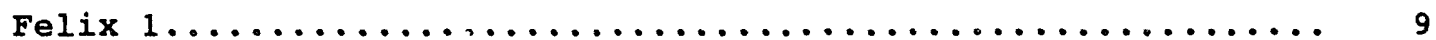

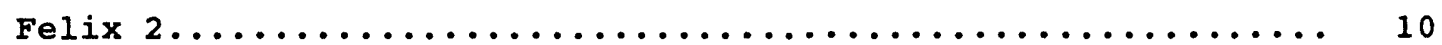

Temporal Changes in Contaminant Concentrations............ 10

RECOMMENDATIONS .................................. 10

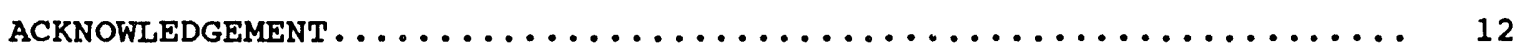

DISCLAIMER .................................... 12

REFERENCES .................................... 13

APPENDIX A. Water Level Measurements.................... 14

APPENDIX B. Contamination concentration................... 19 


\section{LIST OF FIGURES}

\section{Figure}

Page

1. Locations of Wells Sampled During $1990 \ldots \ldots \ldots \ldots \ldots \ldots \ldots$

2. Hoe Creek I/II Highest Contaminant Concentrations for (a) Benzene and (b) Total Phenols..................... 6

3. Hoe Creek III Highest Contaminant Concentrations for (a)

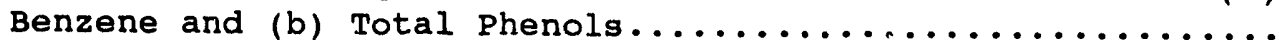




\section{SUMMARY}

Groundwater samples were collected and analyzed for benzene and for total phenols three times during 1990. This report summarizes the results of these sampling events and compares the results with those obtained in previous years. Possible further options for remediation of the Hoe creek site are addressed.

Three underground coal gasification (UCG) burns were performed by Lawrence Livermore National Laboratory for the U.S. Department of Energy in 1976, 1977, and 1979 at the Hoe creek site, which is about $20 \mathrm{miles}$ south of Gillette, wyoming. As a result of these burns, there has been considerable contamination of groundwater by various organic compounds. There have been three efforts at remediating this s: tuation. In 1986 and again in 1987, contaminated water was pumped out, treated, and reinjected. In 1989 , the water was pumped, treated, and sprayed into the atmosphere.

Benzene and total phenols have been monitored at various monitoring wells at the site during 1990. The highest detected benzene concentration in 1990 was $2200 \mu \mathrm{g} / \mathrm{L}$, and the highest total phenols concentration was $430 \mu \mathrm{g} / \mathrm{L}$.

It is apparent that contamination is still above baseline levels, although the concentration of total phenols is far less than immediately after the burns. The burned coal seams are still releasing organic compounds into the groundwater that passes through them. 


\section{INTRODUCTION}

Three underground coal gasification (UCG) burns, Hoe Creek I, II, and III, were performed by Lawrence Livermore National Laboratory for the U.S. Department of Energy (DOE) at the Hoe creek UCG facility southwest of Gillette, Wyoming. The Hoe creek UCG site is 18 miles south of Gillette via Highway 59 (milepost 97), then 5.8 miles west on Hoe creek Road, and then 0.5 miles south. Boundaries of the 80-acre site are approximately marked by a cattle fence. All facilities originally used to conduct the UCG tests have been removed except for groundwater monitoring wells.

The Hoe creek I burn was conducted in 1976, lasted 11 days, and gasified 129 tons of coal, of which at least 9 tons of gasified material was not recovered. The Hoe creek II burn was conducted in 1977 for 58 days and gasified 2480 tons of coal, of which 496 tons of gasified material was not recovered. The Hoe creek III burn was conducted in 1979 for 47 days and gasified 3950 tons of coal, 750 tons of which was not recovered (Hill et al. 1980).

There are three water-bearing units at the Hoe creek site that were affected by the UCG processes. They are referred to as the channel sands, Felix 1, and Felix 2. The Felix 2 coal seam is 24 feet thick and approximately 150 feet below the surface, and it was the target of all three burns. The Felix 1 coal seam is 10 to 12 feet thick and is approximately 130 feet below the surface. The two coal seams are separated by 13 to 17 feet of a claystone-sandstone interburden material. The channel sands unit is above the Felix 1 coal seam. It consists of between 76 and 120 feet of channel sands and siltstone overburden material. The potentiometric surface varies between 35 and 83 feet below the ground surface. Little is known about the recharge or discharge mechanisms of the three water-bearing zones on the site.

Evidence exists (Hill et al. 1980) that the Hoe creek II and III burns extended beyond the targeted Felix 2 coal seam, and involved the claystone-siltstone interburden, the Felix 1 coal seam, and the overlying channel sands zone. Overburden collapse propagated upward at the Hoe Creek III site, causing extensive surface subsidence.

stuermer et al. (1982) report that because the UCG tests were conducted under pressure, 1255 tons of unrecovered gasified coal from the three burns pushed outward and upward from the burn cavity. This gasified coal penetrated the Felix 1 and Felix 2 coal seams as well as the interburden and upper lithologic units. Western Research Institute (WRI) estimates that approximately 58 (or 64 tons) of the gasified coal condensed as coal tars. As groundwater reentered the affected areas, it contacted the condensed coal tars and became contaminated with organic materials (stuermer et al. 1982). stuermer et al. (1982) also identified approximately 100 organic compounds in groundwater at total concentrations up to $50 \mathrm{mg} / \mathrm{L} 15$ months after the last gasification test. These compounds include phenols, aromatic carboxylic acids, aromatic hydrocarbons, ketones, aldehydes, pyridines, quinolones, isoquinolines, and aromatic amines. 
Approximately 150 wells have been drilled on or near the 80-acre site for the purpose of determining the groundwater hydrology and water quality, both before and after the gasification. Many of these wells were drilled downgradient from the cavities after the gasification tests were completed. Wells sampled during 1990 and burn locations are shown in Figure 1.

The DOE has had the groundwater from approximately 30 wells sampled and analyzed for organic and inorganic constituents on an irregular schedule since the completion of gasification processes. Many of the organic and inorganic contaminants decreased as the result of natural processes and several remediation efforts. For example, the phenols concentration in the groundwater sampled at well ws-10 dropped from $37,000 \mu \mathrm{g} / \mathrm{L}$ in 1978 , to $7,000 \mu \mathrm{g} / \mathrm{L}$ in 1981 , to $933 \mu \mathrm{g} / \mathrm{L}$ in 1985 , and to $205 \mu \mathrm{g} / \mathrm{L}$ in 1990. The highest total phenols concentration for wells sampled in 1990 was $430 \mu \mathrm{g} / \mathrm{L}$ in well $\mathrm{w}-4 \mathrm{a}$. Although the concentration of phenols in well ws-10 dropped 978 in the seven years after gasification, only 38 of the decrease has occurred in the last five years.

significant quantities of benzene remain in the groundwater. The very limited information available from Lawrence Livermore National Laboratories (Campbell et al. 1978) suggests that the benzene concentration in the groundwater after the burng was roughly $1000 \mu \mathrm{g} / \mathrm{L}$ or less. The highest concentration of benzene in groundwater sampled from wells in 1990 was $2200 \mu \mathrm{g} / \mathrm{L}$ (well w-22a).

Remediation efforts were performed in 1986,1987 , and 1989. contaminated groundwater was pumped from selected wells; then it was passed through particulate filters and an activated carbon adsorption system. The treated water was reinjected into the Hoe creek II cavity in 1986 and 1987 and was sprayed into the atmosphere in 1989 . During the 1986 remediation program, 129,000 gallons of water was pumped and treated from wells WS-10 and WS-22 over three months (Nolan 1987). The 1987 remediation program pumped and treated 2,034,000 gallons of water from WS -10 and WS-22 (Nordin et al. 1988). The 1989 remediation program pumped 6,500,000 gallons of water from 23 wells (Renk et al. 1990). For the 1986 and 1987 pump-and-treat test, phenols and selected inorganic constituents were monitored. The carbon adsorption unit removed phenols to a concentration below detectable limits $(<20 \mu \mathrm{g} / \mathrm{L})$. For the 1989 program, monitored constituents included ammonia, total organic carbon, sulfate, total dissolved solids, total phenols, benzene, toluene, ethylbenzene, and naphthalene. Renk et al. (1990) calculated that the 1989 pumping removed $23.6 \mathrm{lb}$ of benzene, $5.8 \mathrm{lb}$ of phenols, and lesser amounts of toluene, ethylbenzene, and naphthalene.

\section{RESULTS AND DISCUSSION}

\section{Water Levels}

Water level data are very extensive beginning with the 1989 restoration program. Water levels across the Hoe creek site were measured on a daily basis during the 1989 remediation effort at every 


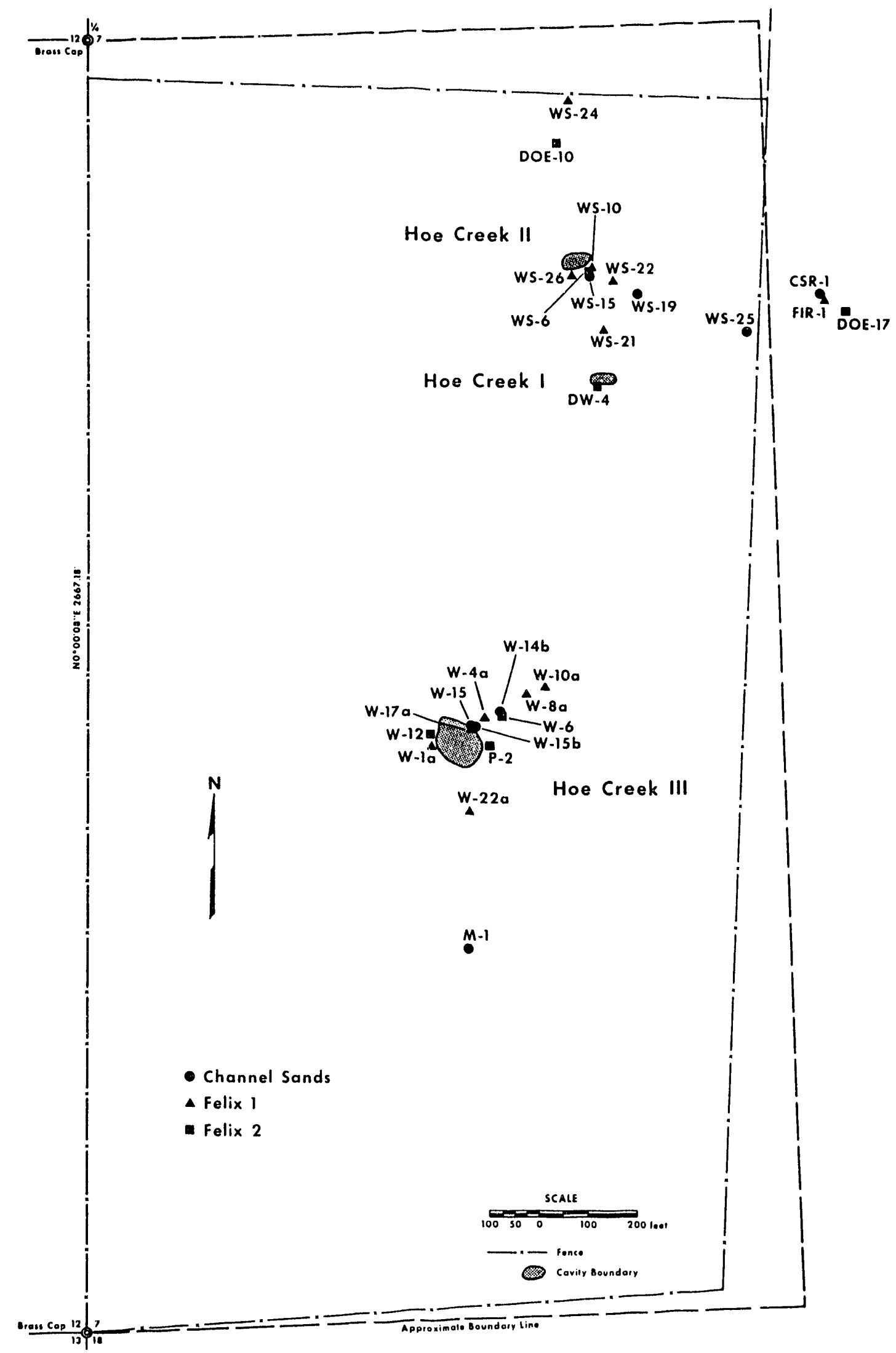

Figure 1. Locations of Wells Sampled During 1990 
accessible monitoring well. Also, water levels were measured at the site for each quarterly sample outing prior to any well purging performed by WRI.

The majority of the measured wells are grouped near to and downgradient from the cavities, producing potentiometric maps with welldefined contours in the cavity areas. These maps are subject to interpretation in the outlying areas. The downward decreasing hydraulic gradient across most of the site causes leakage from the upper into the lower zones (Stone et al. 1983). Because the areas of collapse near the cavities have hydraulic conductivities several orders of magnitude greater than the aquitards, there is a correspondingly greater flow of groundwater through the cavities. This results in groundwater mounds and depressions in the zones near the burn areas.

Around the Hoe creek I and II cavities, potentiometric maps show a groundwater mound in the Felix 2 zone and a groundwater depression in the Felix 1 zone. The data for the channel sands are less definitive in this area, but suggest that water is flowing downward from the channel sands and Felix 1 zones into the Felix 2 zone at the Hoe Creek I and II cavity areas. Equal elevations of the potentiometric surfaces of different zones in wells near the cavities support the concept of increased hydraulic communication between zones through the cavities.

At Hoe Creek III, the Felix 2 shows a groundwater mound around the cavity. A slight depression is apparent in the channel sands and Felix 1 zones. This combination again suggests a downward flow of groundwater from the channel sands and Felix 1 zones into the Felix 2 zone.

Potentiometric maps show that, generally, the groundwater flows toward the southeast in the channel sands zone, to the south in the Felix 1 zone, and to the southeast in the Felix 2 zone. some differences in water levels from one quarterly sampling event to the next were reported by Huntington (1990), suggesting possible seasonal adjustments to the potentiometric surfaces. However, little is known about interactions between seasonal adjustments and contaminant concentrations. Potentiometric maps are part of the quarterly reports by crader and Lindblom (1990a, b) and Huntington (1990). Water level measurements are listed in Appendix $A$.

\section{Contamination Concentrations}

Benzene and total phenols were the two parameters monitored during quarterly sampling in 1990 at the well locations shown in Figure 1 . The contaminant of greatest concern is benzene. Benzene is a nonionic (neutral) compound that has a low water solubility and is slow to biodegrade. Total phenols contamination occurs by processes similar to those of benzene, although phenols are more soluble in water and faster to biodegrade. Renk et al. (1990) reported the egtimated aerial concentrations of benzene and total phenols for the three water-bearing zones at the Hoe creek site during 1988 and during the restoration program of 1989. They showed that the size of the contaminant plumes was reduced as a result of the pump-and-treat remediation method, 
although this method was ineffective at removing source materials. It is important to note that 1988 was the first year that benzene was sampled at enough wells to allow characterization of benzene contamination on the site.

Quarterly sampling was completed three times in 1990. However, too few wells were sampled to draw estimated contamination plumes. Comparisons between contamination concentrations in individual wells are shown in Figures 2 and 3 in an attempt to develop any general trends. All contamination concentrations for wells sampled during 1990 are listed in Appendix B.

For the purposes of the following discussion, the channel sands will be considered as a single unit because not enough information exists to segregate the Hoe creek I and II areas from the Hoe creek III axea. Enough information and differences exist to consider the Felix 1 and Felix 2 zones separately for each area. The Hoe creek I burn and Hoe creek II burn were separate events. Because of the close proximity of the Hoe Creek I burn and the Hoe creek II burn, these will be considered as having one contamination plume. Hereafter, they will be referred to as Hoe creek I/II.

\section{Channel Sands: Benzene}

The highest concentration of benzene recorded in the channel sands in 1990 was $68 \mu \mathrm{g} / \mathrm{I}$ at well wS-15 in February. In August 1990, the benzene concentration was below the analytical detection limit $(<5 \mu \mathrm{g} / \mathrm{L})$ for all wells sampled in the channel sands.

\section{Channel Sands: Total Phenols}

The highest concentration of total phenols detected during quarterly sampling in 1990 was $64 \mu \mathrm{g} / \mathrm{L}$ in well ws-19. As with the benzene concentrations, total phenols have decreased since 1988 .

\section{Hoe Creek I/II, Felix 2: Benzene}

The highest concentration of benzene in this area for 1990 was 200 $\mu \mathrm{g} / \mathrm{L}$ in well DOE-17 in May 1990. This value is comparable to values measured at tha end of the 1989 restoration program. one cause for concern is that this well is located about 600 feet east of the Hoe creek I/II cavities and is outside the eastern boundary of the site.

\section{Hoe Creek I/II, Felix 2: Total Phenols}

The highest concentration of total phenols detected in the Felix 2 zone at the Hoe Creek I/II area was $79 \mu \mathrm{g} / \mathrm{L}$ in well ws-6 in August 1990 . A total phenols concentration of $51 \mu \mathrm{g} / \mathrm{L}$ was measured in DOE-17 at the same time. This suggests that contaminants have migrated across the eastern boundary of the site in this zone. These values are comparable to values obtained during the 1989 restoration program. 

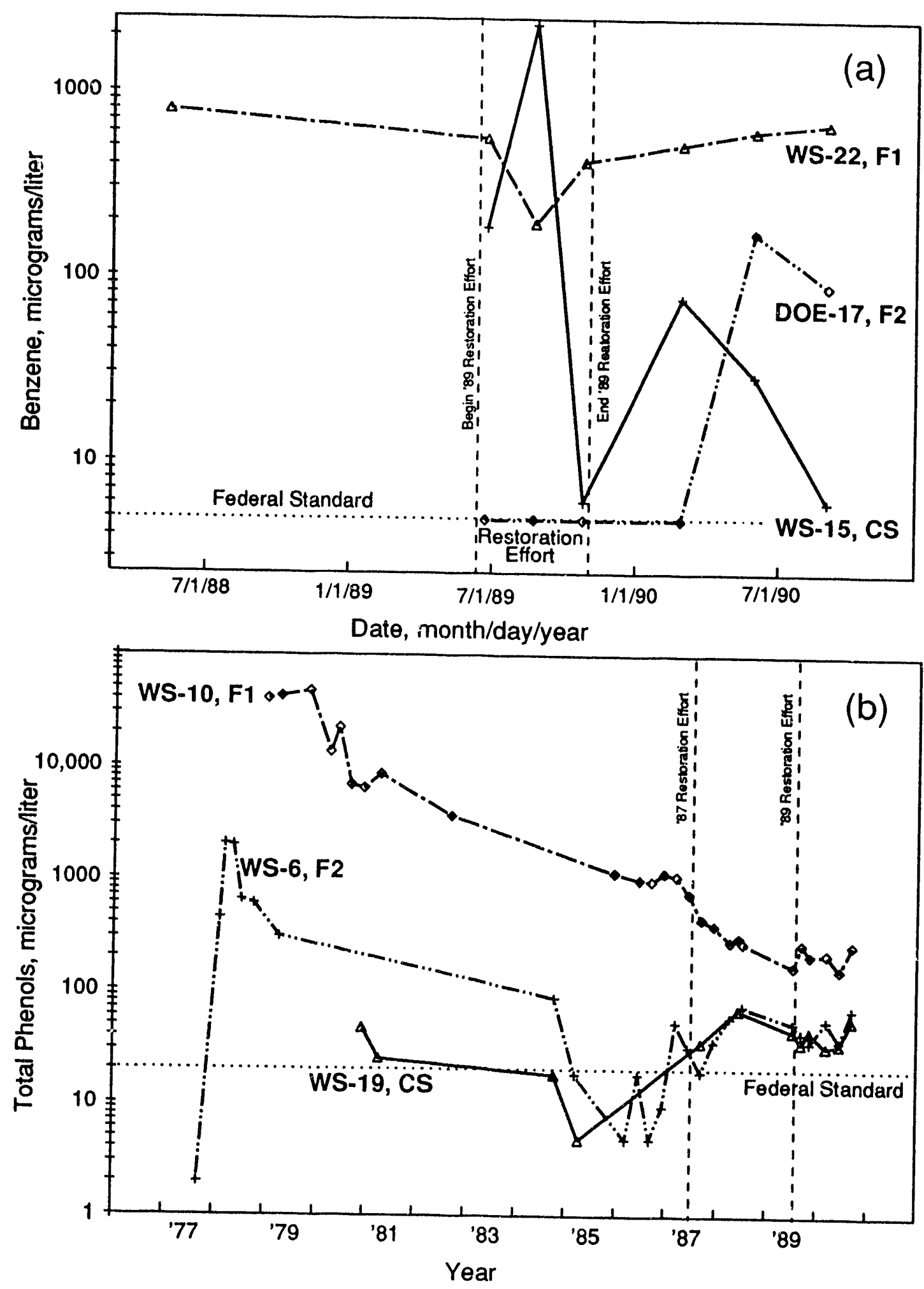

Figure 2. Hoe Creek I/II Highest Contaminant Concentrations for (a) Benzene and (b) Total Phenols 

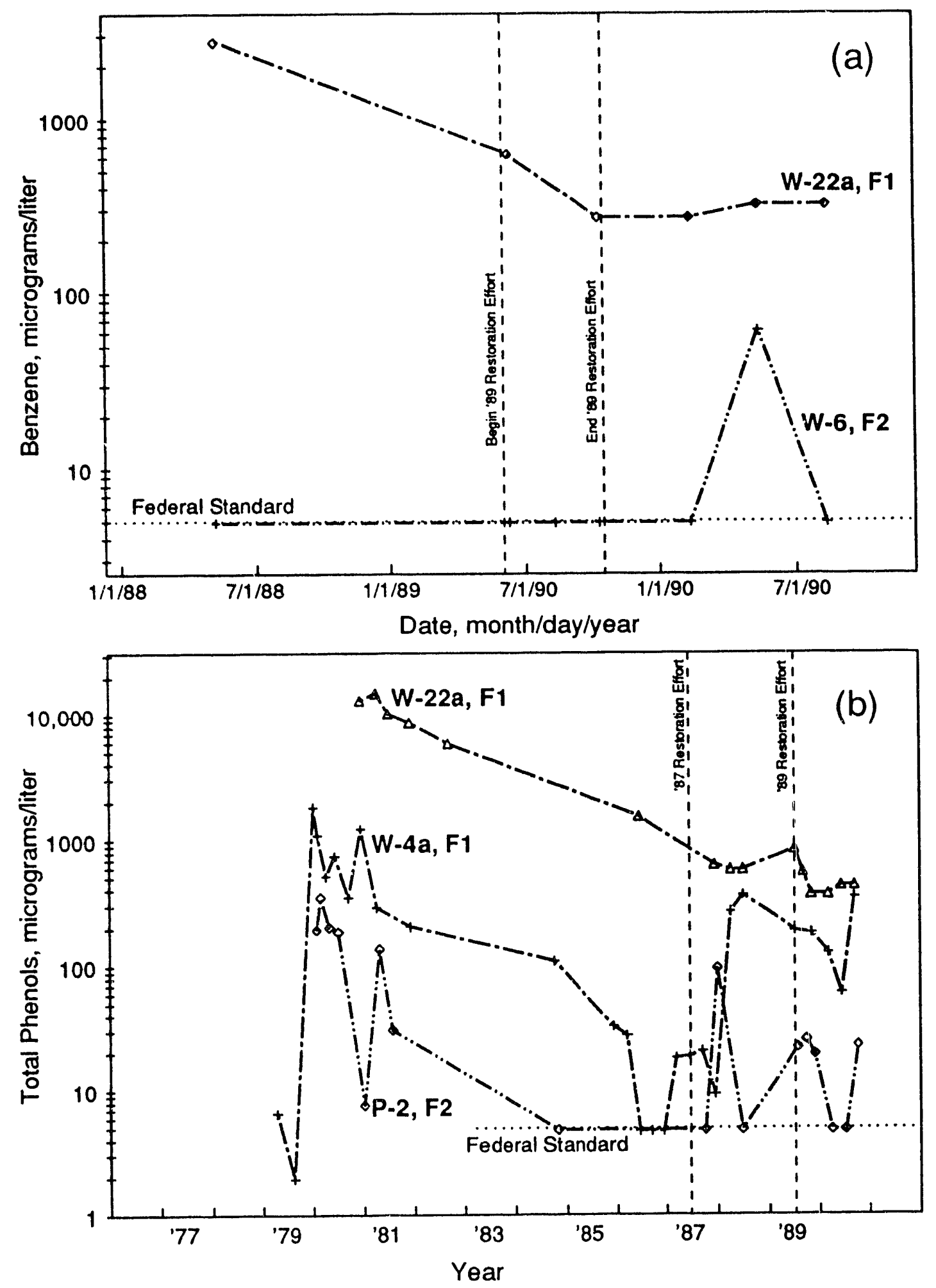

Figure 3. Hoe Creek III Highest Contaminant Concentrations for (a) Benzene and (b) Total Phenols 
Hoe Creek I/II, Felix 1: Benzene

The highest benzene concentration in the Felix 1 zone was $650 \mu \mathrm{m} / \mathrm{L}$, measured in well ws-22 in August 1990. The benzene concentration in well wS-24 decreased from $380 \mu \mathrm{g} / \mathrm{L}$ in February 1990 to below the detection limit of $5 \mu \mathrm{g} / \mathrm{L}$ in August 1990 .

Hoe Creek I/II, Felix 1: Total Phenols

The highest total phenols concentration measured in the Feli 1 zone was $205 \mu \mathrm{g} / \mathrm{L}$ in well wS-10 in August 1990. Total phenols concencrations detectable phenols in well FlR-1, suggesting that contamination in the Felix 1 zone is contained within the boundaries of the Hoe creek site. Total phenols concentrations from 1990 are comparable with concentrations during the 1989 restoration.

Hoe Creek III, Felix 2: Benzene and Total Phenols

Total phenols concentrations were just above detection limits 120 $\mu \mathrm{g} / \mathrm{L}$ ) in well $\mathrm{P}-2$ and well $\mathrm{W}-12$ in August 1990 . All other samples showed total phenols concentrations below the detection limit. The highest benzene concentration measured was $68 \mu \mathrm{g} / \mathrm{L}$ in well $\mathrm{w}-6$ in May 1990. Benzene concentrations remained relatively constant throughout the year.

Hoe Creek III, Felix 1: Benzene and Total Phenols

A benzene concentration of $2200 \mu \mathrm{g} / \mathrm{L}$ was measured in well $\mathrm{W}-22 \mathrm{a}$ in May 1990. This was the highest concentration of benzene measured at the Hoe Creek site during 1990. The highest total phenols concentration measured on the site was $430 \mu \mathrm{g} / \mathrm{L}$ (well w-4a in August 1990). August 1990 total phenols concentrations are higher than those measured in February and May 1990. The benzene and total phenols concentrations measured during 1990 show no consistent trend in this zone near Hoe Creek III. Different trends have been recorded in some wells compared with 1989 concentrations. Some wells show concentration increases, whereas others show decreases.

\section{Temporal Changes in Contamination Concentrations}

Figures 2 and 3 show benzene and total phenols concentrations plotted on a log scale versus time. The wells plotted are those with the highest contaminant concentrations in each zone and region during 1990. Figure 2 shows the benzene and total phenols concentrations in the Hoe Creek I/II area, and Figure 3 shows the concentrations in the Hoe Creek III area. Figure 2 a shows contamination in well DOE-17 beginning in May 1990. Well DOE-17 is outside the eastern boundary of the site. Well WS-22 showed very little decrease in contaminants with time. There were great fluctuations in benzene concentration in well WS -15 . 
Total phenols concentrations for wells wS-6, wS-10, and WS-19 are shown in Figure 2b. Well wS-10 shows a decrease in benzene and total phenols concentrations. Wells WS-6 and WS-19 both show decreases until 1987 and then an increase to present levels.

The Hoe Creek III benzene concentrations for wells $\mathrm{W}-22 \mathrm{a}$ and $\mathrm{H}-6$ are shown in Figure $3 a$. This figure shows a decrease in concentrations and then a constant concentration of benzene and total phenols in well W22a. No concentrations of benzene and total phenols above the detection limit have been detected in the channel sands.

Figure $3 \mathrm{~b}$ shows the total phenols concentrations in the most contaminated wells in the Hoe creek III area. Well W-22a shows a decrease over time. Wells $\mathrm{W}-4 \mathrm{a}$ and $\mathrm{P}-2$ show a decrease until 1987 and then an increase to current levels. There are great fluctuations in contaminant concentrations in these two wells since 1987. Again, there are no data available for the channel sands.

\section{CONCLUSIONS}

\section{Channel Sands}

Although benzene contamination was not detected in the channel sands zone in August 1990, it is possible that contamination exists in this zone at concentrations comparable to the Felix 1 and Felix 2 zones. This conclusion is based on the small number of wells sampled and the location of the wells sampled, specifically at the Hoe creek III site. There are no wells downstream from the Hoe creek III cavity close enough to detect a contamination plume.

There are several possible explanations for the apparent trends in this zone. (1) Contamination levels are expected to decrease over time. (2) The small number of wells and their locations may not allow for sampling in a highly contaminated part of a plume. (3) The groundwater flow may be shifting the contamination plumes. (4) Disturbances, such as the 1989 restoration program, may make detection of contamination difficult. (5) Renk et al. (1990) reported that the contamination plume may exist some distance away from the purged wells. If so, larger volumes of water will have to be pumped to sample highly contaminated water.

\section{Felix 1}

Overall, there was a general trend of decreasing concentrations of benzene in the Hoe creek I/II area during 1990. Well F1R-1 had a benzene concentration below detection limits, suggesting that benzene has not migrated across the eastern boundary of the site in this zone. Benzene concentrations in this zone were much lower than during the 1989 restoration. 
Benzene and total phenols concentrations fluctuated for the different sample outings during 1990 near the Hoe creek III burn area. No discernible pattern of contamination is evident with available data.

\section{Felix 2}

The benzene and total phenols plumes have migrated east of the cavities in the Hoe creek I/II area and extend beyond the boundaries of the site.

\section{Temporal Changes in Contaminant Concentrations}

Figures 2 and 3 show the wells with the highest concentrations of benzene and total phenols during 1990. There has been a decrease in total phenols over time. This may be attributed to the several restoration efforts over the years, to simple diffusion of contamination, to microbial degradation, or to a combination of these. The data from the Hoe creek site show that the greatest concentrations of benzene and total phenols are in the Felix 1. The second most contaminated zone is the Felix 2 , and the least contaminated zone appears to be the channel sands. (There are insufficient data to be certain of the contaminant concentrations in the channel sands.) contaminant concentrations in all three zones are changing, and contaminants have migrated.

The fluctuations in total phenols values shown in Figures $2 b$ and $3 b$ may be attributed to several factors. Different firms have sampled and analyzed the groundwater throughout the years. Different sampling and analytical techniques have been employed to determine contaminant concentrations. The several restoration efforts may have caused changes in the hydrodynamics of the site. There may also be seasonal changes in the contaminant concentrations.

The benzene concentrations in the Felix 1 zone have remained fairly consistent since they were first measured in 1988 . Benzene concentrations immediately after the burns are not available, so the rate of decrease in benzene concentrations is unknown.

\section{RECOMMENDATIONS}

Sampling and analysis must be consistent, both to meet compliance requirements for regulating agencies and to design control, cleanup, or containment technologies. Any site assessment and remediation plan should be based upon consistently acquired data. sampling, preservation, and analytical methods have varied with each of the several organizatjons that have sampled and analyzed Hoe creek groundwater. This has made past data difficult, if not impossible, to use for comparison (Barteaux 1986). Further research is needed on the hydrologic mechanisms of the site (Barteaux 1986) to select appropriate sampling wells and frequencies. Little data are available on either groundwater recharge and discharge mechanisms or on fluctuations in groundwater characteristics due to seasonal variations. 
Contamination exists on the site above accepted drinking water standards. Nordin et al. (1990) developed remediation and cleanup options for the Hoe creek UCG site. The recommendations of this report should be followed, particularly the recommendation that source materials be obtained for laboratory testg of in situ remediation technologies.

other recommendations involve characterization of the areas of the site where questions and data gaps exist. The aerial extent of the contaminated plume across the eastern boundary of the site should be cletermined. This will require drilling several monitoring wells downgradient from the cavities.

Another problem is the lack of data in the channel sands zone. Renk et al. (1990) concluded that high concentrations of contaminants are in the channel sands zone. This conclusion is based on the upward direction of the burn during gasification processes and on contaminant concentrations previously seen in this zone, particularly near the Hoe creek I/II cavities. The data obtained from the channel sands zone during 1990 do not support this conclusion. The limited number of wells completed in the channel sands make it difficult to characterize this zone, specifically near the Hoe creek III cavity. Wells need to be drilled downgradient from the cavities in this zone to determine the concentration and extent of contamination.

Changes in sampling procedure and in analyses performed may fill in some gaps in the data. Instead of sampling the same twenty-five wells three times, we recommended sampling seventy-five wells once. This can be done by sampling 25 channel sands wells during one quarterly outing, 25 Felix 1 wells during the next outing, and 25 Felix 2 wells during the next outing. This should provide enough data in each zone to predict the location of contaminant plumes. Scheduling sampling events to coincide with periods of high and low surface and groundwater flows will enable characterization of groundwater and contaminant plume behavior. Parameters such as total organic carbon, total dissolved solids, all volatile organic compounds, and all semivolatile compounds should be included in the sample suites to determine if there are other constituents that will influence the characterization of the site and the design of any future restoration efforts.

one other recommendation involves data analysis. All available data should be entered into a data base that is be made available to all parties involved with the Hoe Creek site. Statistical analysis of the data should be done to determine the significance of contaminant concentration changes. Statistical analysis may show data points that are possible outliers, thereby, decreasing the variability between sampling efforts performed by different organizations.

In sumnary, efforts need to be made to completely characterize the Hoe Creek site. Drilling new wells, obtaining core borings, changing the sampling procedures, and performing statistical analyses are methods that will help to achieve this goal. The ultimate goal of returning the groundwater to acceptable water quality standards can be met by following the recommendations of Nordin et al. (1990). The environmental, economical, and legal implications of allowing this contamination to continue need to be assessed. 


\section{ACKNOWLEDGEMENT}

The authors express appreciation to the United States Department of Energy for funding of this work under Cooperative Agreement Number DEFC21-86MC11076 and Grant Number DE-FG21-88MC25038.

\section{DISCLAIMER}

Mention of specific brand names or models of equipment is for information only and does not imply endorsement of any particular brand. 


\section{REFERENCES}

Barteaux, W.I., G.I. Berdan, and J. Lawrence, 1986, Elvironmental Evaluation and Restoration Plan of the Hoe Creek Underground Coal Gasification site, Wyoming, Laramie, WY, WRI Report to DOE, Report DOE/MC/11076-2641.

Campbe11, J.H., E. Pellizzari, and S. Santor, 1978, Resultg of a Groundwater Quality study Near an Underground Coal Gasification Experiment (Hoe Creek I). Lawrence Livermore Laboratory, Livermore, Ca, UCRL-52405.

Crader, S., and s. Lindblom, 1990a, Sampling and Analyses Report for February 1990 Quarterly at the Hoe creek sites, Gillette, Wyoming, Western Research Institute, Laramie, WY, U.S. Department of Energy Report WRI-91-R026.

Crader, S., and S. Iindblom, 1990b, Quarterly Sampling and Analyses Report, Hoe Creek Sites, Gillette, Wyoming, Laramie, WY, WRI Report to DOE, WRI-91-R027.

Hill, R.W., C.B. Thorsness, R.J. Cena, W.R. Aiman, and D.R. Stephens, 1980, Results from the Third Lawrence Livermore Laboratory's Underground Coal Gasification Experiment at Hoe Creek. Proceedings of the sixth Underground Coal Conversion symposium, Shangri-la, OK, I-19- I-29.

Huntington, G., 1990 , Hoe creek August 1990 Quarterly Groundwater Sampling, Laramie, WY, WRI Report to DOE, Report WRI-90-R039.

Nolan, B.T., 1987, Results of the Groundwater Treatment Demonstration at the Hoe Creek Underground Coal Gasification Site, Western Research Institute, Laramie, WY. Unpublished Report to DOE.

Nordin, J.S., W. Barrash, and B.T. Nolan, 1988, Groundwater Restoration Field Test at the Hoe creek Underground Coal Gasification site. Western Research Institute, Laramie, WY, WRI Report to DOE, Report $\mathrm{DOE} / \mathrm{MC} / 11076-2454$.

Nordin, J., W. Griffin, T. Chatwin, S. Lindblom, and J.R. Covell, 1990, Remediation Cleanup options for the Hoe Creek UCG Site, Laramie, WY, WRI Report to DOE, WRI-90-R034.

Renk, R.R., S.E. Crader, S.R. Lindblom, and J.R. Covell, 1990, Hoe Creek Groundwater Restoration 1989, Laramie, WY, WRI Report to DOE, Report $\mathrm{DOE} / \mathrm{MC} / 11076-2948$.

stone, R., E. Raber, and A.M. Winslow, 1983 , Effects of Aquifer Interconnection Resulting from Underground coal Gasification, Lawrence Livermore Laboratory, Livermore, CA, UCRL-87722, Rev. 1 .

Stuermer, D.A., D.J. Ng, and C.J. Morris, 1982, organic Contaminants in Groundwater near an Underground Coal Gasification in Northeastern Wyoming, Environmental Science and Technology, 16(9): 582-587. 
APPENDIX A

Water Level Measurements

14 
CONTENTS OF APPENDIX A

$\underline{\text { Table }}$

Page

A1. Water Levels and Elevations at the Hoe Creek UCG Site on

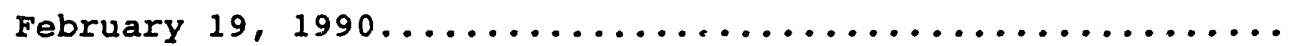

A2. Water Levels and Elevations at the Hoe Creek UCG site on

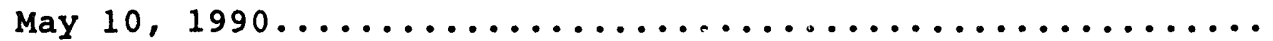

A3. Water Levels and Elevations at the Hoe Creek UCG Site on

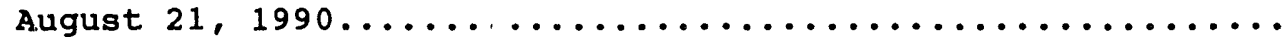


Table Al. Water Levels and Elevations at the Hoe Creek ucG site on February 19, 1990

\begin{tabular}{|c|c|c|c|c|c|}
\hline Well & $\begin{array}{l}\text { Water } \\
\text { Depth, } \mathrm{ft}\end{array}$ & $\begin{array}{c}\text { Water } \\
\text { Elevation, } \mathrm{ft}\end{array}$ & Well & $\begin{array}{l}\text { Water } \\
\text { Depth, ft }\end{array}$ & $\begin{array}{c}\text { Water } \\
\text { Elevation, } \mathrm{ft}\end{array}$ \\
\hline CSR-1 & 43.35 & 4672.1 & $\mathrm{P}-1$ & 111.05 & 4673.0 \\
\hline DOE-1 & 110.45 & 4677.2 & $P-3$ & 109.7 & 4671.3 \\
\hline DOE-2 & 111.25 & 4676.1 & PERM-2 & 113.65 & 4669.4 \\
\hline DOE-3 & 116.35 & 4670.6 & $w-1 a$ & 106.5 & 4671.5 \\
\hline $\mathrm{DOE}-4$ & 85.95 & 4674.3 & $w-3$ & 117.45 & 4668.6 \\
\hline DOE-5 & 85.5 & 4673.9 & $w-4 a$ & 114.9 & 4671.1 \\
\hline DOE-6 & 87.85 & 4670.8 & $w-6$ & 117.65 & 4668.4 \\
\hline DOE-7 & $<54.3$ & $<4679.3^{a}$ & W-7 & 114.6 & 4668.4 \\
\hline DOE- 8 & 65.1 & 4667.8 & $w-8 a$ & 112.2 & 4671.8 \\
\hline DOE-9 & 62.75 & 4669.5 & W-9 & 105.5 & 4668.5 \\
\hline DOE-10 & 64.25 & 4669.0 & $w-10 a$ & 103.5 & 4671.5 \\
\hline DOE-11 & 59.25 & 4667.6 & W-11 & 86.4 & 4668.6 \\
\hline DOE-14 & 71.45 & 4671.5 & W-12 & 109.6 & 4669.4 \\
\hline DOE-17 & 45.9 & 4669.3 & W-13 & 117.45 & 4668.6 \\
\hline DOE-39 & 97.2 & 4669.4 & $w-14 b$ & 116.15 & 4667.9 \\
\hline DOE-40 & 97.2 & 4669.0 & $w-16 a$ & 60.05 & 4672.0 \\
\hline DOE-44 & 96.55 & 4669.7 & $w-17 a$ & 112.9 & 4671.1 \\
\hline DOE-49 & 81.85 & 4668.7 & $w-18 a$ & 109.4 & 4669.6 \\
\hline DOE-50 & 80.65 & 4669.8 & $w-19 b$ & $<98.8$ & $<4680.2^{a}$ \\
\hline DOE-54 & $<80.5$ & $<6471.7^{a}$ & $w-21$ & 112.55 & 4671.5 \\
\hline DOE-59 & 109.8 & 4673.5 & $w-22 a$ & 114.0 & 4671.0 \\
\hline DOE-60 & 112.15 & 4671.1 & WS-5 & 64.5 & 4671.5 \\
\hline DOE-64 & 107.65 & 4675.7 & wS -6 & 65.2 & 4668.8 \\
\hline DW-1 & 73.75 & 4670.3 & wS-7 & 65.4 & 4669.6 \\
\hline$D W-3$ & 74.65 & 4669.4 & WS- 8 & 63.8 & 4669.5 \\
\hline $\mathrm{DW}-5$ & 73.9 & 4669.1 & WS-9 & 59.6 & 4668.9 \\
\hline EM-1 & 64.70 & 4669.3 & WS -10 & 62.95 & 4672.1 \\
\hline EM-2 & 68.0 & 4669.0 & WS -13 & 53.35 & 4668.7 \\
\hline$E M-3$ & 75.95 & 4670.1 & WS-14 & 50.0 & 4672.0 \\
\hline$E M-4$ & 68.55 & 4669.5 & ws-15 & 64.5 & 4672.0 \\
\hline EM-5 & 71.7 & 4669.1 & WS-16 & 63.6 & 4672.0 \\
\hline EXP-4 & 49.8 & 4674.2 & WS-17 & 64.85 & 4672.0 \\
\hline$F 1 R-1$ & 42.75 & 4672.1 & WS-19 & 58.7 & 4675.5 \\
\hline F $1 R-2$ & 64.35 & 4676.5 & WS-20 & 68.8 & 4673.2 \\
\hline$M-1$ & 122.5 & 4669.5 & WS-21 & 64.6 & 4672.4 \\
\hline$M-2$ & 110.25 & & WS-22 & 61.2 & 4671.8 \\
\hline$M-3$ & 112.5 & 4670.6 & WS -23 & 58.75 & 4673.3 \\
\hline OW- 10 & 69.8 & 4673.2 & WS-24 & 57.1 & 4671.9 \\
\hline OW-12 & 70.05 & 4672.0 & WS-25 & 50.05 & 4672.0 \\
\hline $\mathbf{P}$ & 73.2 & 4668.2 & WS-26 & 64.7 & 4672.3 \\
\hline
\end{tabular}

a Well was dry. Depth and elevation are the bottom of the well. 
Table A2. Water Levels and Elevations at the Hoe Creek UCG site on May 10,1990

\begin{tabular}{|c|c|c|c|c|c|}
\hline & water & Water & & Water & Water \\
\hline Well & Depth, ft & Elevation, $\mathrm{ft}$ & Well. & Depth, ft & Elevation, ft \\
\hline A & 62.6 & 4674.0 & $P-3$ & 109.15 & 4671.9 \\
\hline CSR-1 & 42.95 & 4672.5 & PERM-2 & 113.9 & 4669.2 \\
\hline DOE-1 & 110.0 & 4677.6 & $w-1 a$ & 106.0 & 4672.0 \\
\hline DOE-2 & 110.85 & 4676.5 & $\mathrm{~W}-3$ & 117.4 & 4668.6 \\
\hline DOE-3 & 116.75 & 4670.2 & $w-4 a$ & 114.35 & 4671.7 \\
\hline DOE-4 & 85.70 & 4674.5 & $w-6$ & 117.6 & 4668.4 \\
\hline DOE-5 & 85.15 & 4674.3 & $W-7$ & 114.55 & 4668.5 \\
\hline DOE-6 & 88.05 & 4670.5 & $w-8 a$ & 111.65 & 4672.4 \\
\hline DOE -7 & 53.4 & $4680.2^{a}$ & $\mathrm{~W}-9$ & 105.35 & 4668.7 \\
\hline DOE-8 & 64.7 & 4668.4 & $w-10 a$ & 102.9 & 4672.1 \\
\hline DOE-9 & 62.7 & 4669.8 & $\mathrm{w}-11$ & 86.4 & 4668.6 \\
\hline DOE-10 & 64.35 & 4668.9 & $w-12$ & 109.55 & 4669.5 \\
\hline DOE-11 & 59.35 & 4667.5 & $w-13$ & 117.4 & 4668.6 \\
\hline DOE-14 & 71.50 & 4671.5 & $w-14 b$ & 115.55 & 4671.5 \\
\hline DOE-17 & 45.15 & 4670.0 & $\mathrm{~W}-15 \mathrm{~b}$ & 112.35 & 4671.7 \\
\hline DOE-39 & 96.85 & 4669.8 & $w-16 a$ & 59.45 & 4672.6 \\
\hline $\mathrm{DOE}-40$ & 97.05 & 4669.3 & $\mathrm{~W}-17 \mathrm{a}$ & 112.5 & 4671.5 \\
\hline $\mathrm{DOE}-44$ & 96.25 & 4670.1 & $\mathrm{~W}-18 \mathrm{a}$ & 109.25 & 4669.8 \\
\hline DOE-49 & 81.4 & 4669.2 & $w-19 b$ & 58.0 & $4721.0^{a}$ \\
\hline DOE-50 & 80.75 & 4669.8 & W-21 & 112.1 & 4671.9 \\
\hline DOE-54 & 80.0 & $4672.2^{a}$ & $w-22 a$ & 113.45 & 4671.6 \\
\hline DOE-59 & 109.6 & 4673.7 & WS-5 & 64.25 & 4671.8 \\
\hline DOE-60 & 112.35 & 4671.1 & WS- 6 & 65.05 & 4669.0 \\
\hline DOE-64 & 107.2 & 4676.2 & ws - 7 & 65.3 & 4669.7 \\
\hline DW-1 & 73.45 & 4670.6 & WS -8 & 64.7 & 4668.6 \\
\hline$D W-3$ & 74.4 & 4669.6 & ws-9 & 59.55 & 4669.0 \\
\hline$D W-4$ & 72.6 & 4671.4 & WS-10 & 62.45 & 4672.6 \\
\hline DW-5 & 73.65 & 4669.4 & WS- 12 & 58.1 & 4671.9 \\
\hline DW- 6 & 73.7 & 4670.3 & WS- 13 & 53.3 & 4668.7 \\
\hline$E M-1$ & 64.6 & 4669.4 & WS-14 & 49.5 & 4672.5 \\
\hline EM-2 & 67.9 & 4669.1 & wS -15 & 63.9 & 4672.6 \\
\hline EM-3 & 75.85 & 4670.2 & WS-16 & 62.95 & 4672.7 \\
\hline EM-4 & 68.35 & 4669.7 & WS-: 7 & 64.3 & 4672.6 \\
\hline EM-5 & 71.45 & 4669.4 & WS-19 & 58.1 & 4676.0 \\
\hline$E X P-4$ & 49.45 & 4674.6 & WS-20 & 68.15 & 4673.9 \\
\hline$F 1 R-1$ & 42.3 & 4672.6 & WS-21 & 64.1 & 4672.9 \\
\hline F1R-2 & 64.15 & 4676.7 & wS-22 & 60.75 & 4672.3 \\
\hline $\mathbf{M}-1$ & 122.0 & 4670.0 & WS- 23 & 58.35 & 4673.7 \\
\hline M-3 & 112.25 & 4670.9 & WS-24 & 56.55 & 4672.5 \\
\hline OW-10 & 69.75 & 4673.3 & WS-25 & 49.55 & 4672.5 \\
\hline ow-12 & 69.55 & 4672.5 & WS-26 & 64.15 & 4672.9 \\
\hline $\mathbf{P}$ & 72.95 & 4668.5 & WW-3 & 75.4 & 4669.6 \\
\hline$P-1$ & 110.65 & 4673.4 & WW-3a & 74.5 & 4670.3 \\
\hline$P-2$ & 116.0 & 4669.0 & & & \\
\hline
\end{tabular}

a Well was dry. Depth and elevation are the bottom of the well. 
Table A3. Water Levels and Elevations at the Hoe creek ucG site on August, 21, 1990

\begin{tabular}{|c|c|c|c|c|c|}
\hline Well & $\begin{array}{l}\text { Water } \\
\text { Depth, ft }\end{array}$ & $\begin{array}{c}\text { Water } \\
\text { Elevation, } \mathrm{ft}\end{array}$ & Well & $\begin{array}{l}\text { Water } \\
\text { Depth, ft }\end{array}$ & $\begin{array}{c}\text { Water } \\
\text { Elevation, ft }\end{array}$ \\
\hline CSR-1 & 42.80 & 4672.7 & $P-2$ & 116.25 & 4668.8 \\
\hline DOE-1 & 110.10 & 4677.5 & PERM-2 & 114.25 & 4668.9 \\
\hline DOE-2 & 110.85 & 4676.5 & $w-1 a$ & 105.90 & 4672.1 \\
\hline DOE-3 & 117.05 & 4669.9 & $w-3$ & 117,70 & 4668.3 \\
\hline DOE-4 & 85.70 & 4674.5 & $w-4 a$ & 114.25 & 4671.8 \\
\hline DOE-5 & 85.15 & 4674.3 & พ-6 & 117.85 & 4668.2 \\
\hline DOE-6 & 88.40 & 4670.2 & $w-7$ & 114.75 & 4668.3 \\
\hline DOE-7 & 52.00 & $4679.0^{a}$ & $W-8 a$ & 111.60 & 4672.5 \\
\hline DOE-8 & 64.95 & 4668.2 & $w-9$ & 105.60 & 4668.5 \\
\hline DOE-9 & 63.25 & 4669.3 & $\mathrm{w}-10 \mathrm{a}$ & 102.85 & 4672.2 \\
\hline DOE-10 & 64.60 & 4668.7 & $\mathrm{~W}-11$ & 86.65 & 4668.4 \\
\hline DOE-11 & 59.60 & 4667.3 & $\mathrm{w}-12$ & 109.80 & 4669.3 \\
\hline DOE-14 & 71.70 & 4671.3 & $w-13$ & 117.70 & 4668.3 \\
\hline DOE-17 & 44.40 & 4670.8 & $W-14 b$ & 115.45 & 4671.6 \\
\hline DOE-39 & 97.05 & 4669.6 & $w-16 a$ & 59.40 & 4672.7 \\
\hline DOE -40 & 97.35 & 4669.0 & $w-17 a$ & 112.35 & 4671.7 \\
\hline DOE-44 & 96.50 & 4669.9 & W-18a & 109.25 & 4669.8 \\
\hline DOE-50 & 82.30 & 4669.3 & $w-19 b$ & 108 & $4671.0^{a}$ \\
\hline DOE-51 & 82.20 & $4669.4^{a}$ & $W-21$ & 112.00 & 4672.0 \\
\hline DOE-59 & 109.80 & 4673.5 & $w-22 a$ & 113.45 & 4671.6 \\
\hline DOE- 60 & 112.65 & 4670.8 & WS-6 & 65.20 & 4668.9 \\
\hline DOE-64 & 107.30 & 4676.1 & พs -7 & 65.45 & 4669.6 \\
\hline DW-1 & 73.60 & 4670.5 & WS- 8 & 63.90 & 4669.4 \\
\hline DW-3 & 74.50 & 4669.5 & WS-9 & 59.80 & 4668.8 \\
\hline DW-4 & 71.70 & 4672.3 & WS -10 & 62.30 & 4672.8 \\
\hline$D W-5$ & 73.75 & 4669.3 & WS -13 & 53.55 & 4668.5 \\
\hline EN-1 & 64.85 & 4669.2 & WS-14 & 49.40 & 4672.6 \\
\hline$E M-2$ & 68.10 & 4668.9 & WS -15 & 63.80 & 4672.7 \\
\hline EM-3 & 75.15 & 4669.9 & WS-16 & 62.85 & 4672.8 \\
\hline EM-4 & 68.50 & 4669.6 & WS -17 & 64.20 & 4672.7 \\
\hline EM-5 & 71.55 & 4669.3 & WS-19 & 58.00 & 4676.1 \\
\hline EXP-4 & 49.35 & 4674.7 & WS-20 & 68.05 & 4674.0 \\
\hline F $1 R-1$ & 42.15 & 4672.8 & WS-21 & 64.00 & 4673.0 \\
\hline F $1 R-2$ & 64.15 & 4676.7 & WS-22 & 60.60 & 4672.5 \\
\hline$M-1$ & 122.10 & 4669.9 & WS-23 & 58.15 & 4673.9 \\
\hline$M-3$ & 112.35 & 4670.8 & WS-24 & 56.45 & 4672.6 \\
\hline OW-10 & 69.55 & 4673.5 & WS-25 & 49.45 & 4672.6 \\
\hline OW-12 & 69.45 & 4672.6 & WS-26 & 64.05 & 4673.0 \\
\hline $\mathbf{P}$ & 73.05 & 4668.4 & & & \\
\hline$P-1$ & 110.50 & 4673.6 & & & \\
\hline
\end{tabular}

a Well was dry. Depth and elevation are the bottom of the well. 
APPENDIX B

Contamination Concentration 


\section{CONTENTS OF APPENDIX B}

B1. Concentrations of Benzene and Total Phenols in Wells sampled at the Hoe Creek site in February $1990 \ldots \ldots \ldots \ldots \ldots \ldots \ldots \ldots$

B2. Concentrations of Benzene and Total Phenols in Wells Sampled at the Hoe creek site in May $1990 \ldots \ldots \ldots \ldots \ldots \ldots \ldots \ldots \ldots \ldots$

B3. Concentrations of Benzene and Total Phenols in Wells Sampled at the Hoe Creek site in August $1990 \ldots \ldots \ldots \ldots \ldots \ldots \ldots \ldots$ 
Table B1. Concentrations of Benzene and Total Phenols in Wells Sampled at the Hoe Creek Site in February 1990

Hoe Creek I \& II

Channel sands

WS-15

WS-19

WS -25

\section{Felix 1}

F1R-1

WS -10

WS-21

WS-22

WS-24

WS-26

Felix 2

DOE-10

DOE-17

DW-4

WS-6

\section{Hoe Creek III}

Channel sands

M-1

$\mathrm{W}-14 \mathrm{~b}$

W-15

Felix 1

w-la

$W-4 a$

$\mathrm{W}-8 \mathrm{a}$

w-10a

w-17a

$\mathrm{w}-22 \mathrm{a}$

Felix 2

P-2

W-6

W-12
68

$<5$

$<5$

44

37

$<20$

$<5$

460

190

500

380

200

$<5$

$<5$

$<5$

86

$<20$

170

61

140

61

190

$<20$

68

$<20$

63
$<5$

$<5$

$<5$

1300

1500

590

310

120

1600

33

$<5$

42
$<20$

$<20$

$<20$

190

150

160

82

220

320

$<20$

$<20$

$<20$ 
Table B2. Concentrations of Benzene and Total Phenols in Wells Sampled at the Hoe Creek site in May 1990

Benzene, $\mu \mathrm{g} / \mathrm{I}$

Total Phenols, $\mu \mathrm{g} / \mathrm{I}$

Hoe Creek I \& II

Channel Sands

CSR-1

WS -15

WS -19

$<5$

25

44

Felix 1

FIR-1

WS -10

WS -21

WS -22

WS-24

พS -26

Felix 2

DOE-10

DOE-17

DW-4

WS- 6

Hoe Creek III

Channel sands

M-1

W-1 $4 b$

W-15b

Felix 1

W-1a

$w-4 a$

$\mathrm{W}-8 \mathrm{a}$

w-10a

w-17a

$w-22 a$

Felix 2

P-2

W -6

W-12
$<5$

$<5$

$<5$

1400

1300

780

560

$130,140^{\mathrm{a}}$

2200

42
68
$41,40^{a}$
$<20$

$<20$

39

$<20$

120

70

120

58

160

$<20$

33

$<20$

41

$<20$

$<20$

$<20$

210

71

130

100

220

380

a original and duplicate samples analyzed. 
Table B3. Concentrations of Benzene and Total Phenols in Wells Sampled at the Hoe Creek site in August 1990

Benzene, $\mu \mathrm{g} / \mathrm{L}$

Total Phenols, $\mu \mathrm{g} / \mathrm{I}$

Hoe Creek I \& II

Channel sands

CSR-1

WS -15

WS -19

Felix 1

F1R-1

WS -10

WS-2 1

WS-22

WS-24

WS -26

Felix 2

DOE-10

DOE-17

DW-4

WS- 6

\section{Hoe Creek III}

Channel sands

M-1

W-1 $4 b$

w-15b

Felix 1

w-1a

$\mathrm{W}-4 \mathrm{a}$

$w-8 a$

w-10a

w-17a

$\mathrm{w}-22 \mathrm{a}$

Felix 2

P-2

W-6

W-12
$<5$

$<5$

$<5$

$<5$

$340 / 240^{a}$

$<5$

650

$<5$

190

$<5$

100

$12 / 11^{a}$

$<5 /<5^{a}$
31

$<20$

64

$<20$

$190 / 220^{a}$

120

200

76

200

$<20$

51

25

79
$<5$

$<5$

$<5$

1100

1200

800

360

97

1400

36

$<5$

54
22

$<20$

$<20$

300

430

340

140

240

380

25

$<20$

21

a Original and duplicate samples analyzed. 


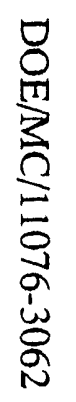

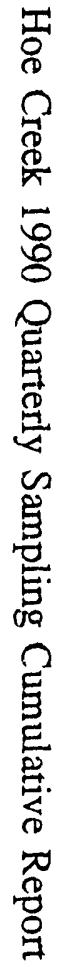

뭉 

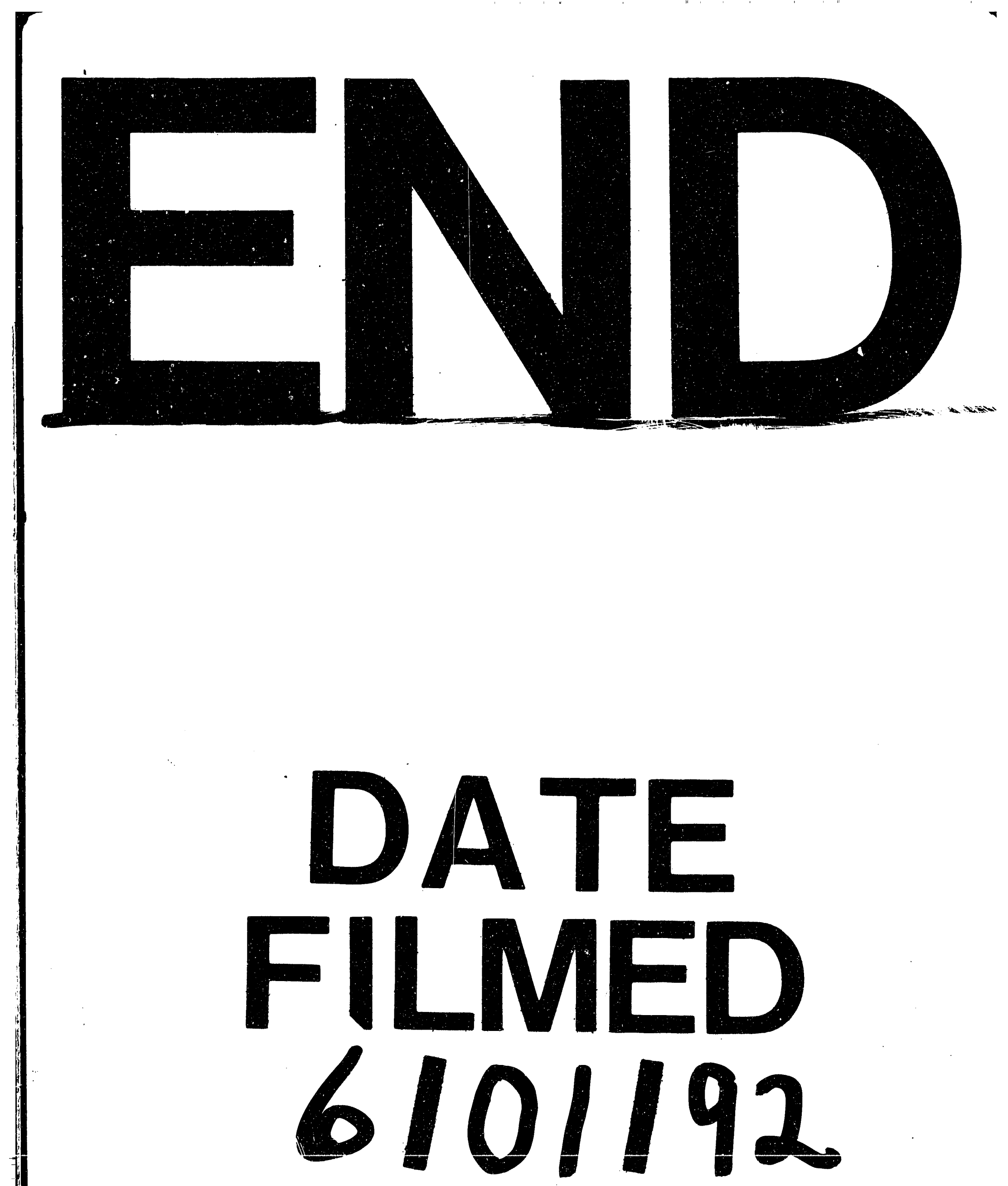
